\title{
Determining the stable isotope composition of pore water from saturated and unsaturated zone core: improvements to the direct vapour equilibration laser spectrometry method
}

\author{
M. J. Hendry ${ }^{1}$, E. Schmeling ${ }^{1}$, L. I. Wassenaar ${ }^{1,3}$, S. L. Barbour ${ }^{2}$, and D. Pratt ${ }^{2}$ \\ ${ }^{1}$ Department of Geological Sciences, University of Saskatchewan, 114 Science Place, Saskatoon, SK, S7N 5E2, Canada \\ ${ }^{2}$ Department of Civil and Geological Engineering, University of Saskatchewan, 57 Campus Drive, Saskatoon, \\ SK, S7N 5A9, Canada \\ ${ }^{3}$ International Atomic Energy Agency, Vienna International Centre, 1400 Vienna, Austria
}

Correspondence to: M. J. Hendry (jim.hendry@usask.ca)

Received: 25 May 2015 - Published in Hydrol. Earth Syst. Sci. Discuss.: 30 June 2015

Revised: 13 October 2015 - Accepted: 26 October 2015 - Published: 4 November 2015

\begin{abstract}
A method to measure the $\delta^{2} \mathrm{H}$ and $\delta^{18} \mathrm{O}$ composition of pore waters in saturated and unsaturated geologic core samples using direct vapour equilibration and laser spectrometry (DVE-LS) was first described in 2008, and has since been rapidly adopted. Here, we describe a number of important methodological improvements and limitations encountered in routine application of DVE-LS over several years. Generally, good comparative agreement, as well as accuracy, is obtained between core pore water isotopic data obtained using DVE-LS and that measured on water squeezed from the same core. In complex hydrogeologic settings, high-resolution DVE-LS depth profiles provide greater spatial resolution of isotopic profiles compared to long-screened or nested piezometers. When fluid is used during drilling and coring (e.g. water rotary or wet sonic drill methods), spiking the drill fluid with ${ }^{2} \mathrm{H}$ can be conducted to identify core contamination. DVE-LS analyses yield accurate formational isotopic data for fine-textured core (e.g. clay, shale) samples, but are less effective for cores obtained from saturated permeable (e.g. sand, gravels) geologic media or on chip samples that are easily contaminated by wet rotary drilling fluid. Data obtained from DVE-LS analyses of core samples collected using wet (contamination by drill water) and dry sonic (water loss by heating) methods were also problematic. Accurate DVE-LS results can be obtained on core samples with gravimetric water contents $>5 \%$ by increasing the sample size tested. Inexpensive Ziploc ${ }^{\mathrm{TM}}$ gassampling bags were determined to be as good as, if not bet-
\end{abstract}

ter than, other, more expensive specialty bags. Sample storage in sample bags provides acceptable results for up to 10 days of storage; however, measurable water loss, as well as evaporitic isotopic enrichment, occurs for samples stored for up to 6 months. With appropriate care taken during sample collection and storage, the DVE-LS approach for obtaining high-resolution pore water isotopic data is a promising alternative to study the hydrogeology of saturated and unsaturated sediments. Eliminating analytical interferences from volatile organics remains a challenge.

\section{Introduction}

The stable isotope composition of pore water $\left(\delta^{2} \mathrm{H}, \delta^{18} \mathrm{O}\right)$ in unsaturated and saturated zone geologic media is an important hydrologic tracer used to determine the origin, rate of water movement, and mixing of different waters; this method has been applied to studies evaluating resources, the water cycle, and groundwater contamination, as well as those determining soil vapour fluxes (e.g. Clark and Fritz, 1997; Gimmi et al., 2007; Mueller et al., 2014). The method of core sampling and subsequent isotope analysis $\left(\delta^{2} \mathrm{H}\right.$ and $\left.\delta^{18} \mathrm{O}\right)$ is best applied when the objective of a study is to characterize vertical and spatial variability of the stable isotopes of water rather than temporal variability. Traditional approaches for obtaining pore water stable isotope depth profiles from geologic media generally require the installation of wells or 
piezometers (saturated zone) or suction lysimeters (unsaturated zone) to obtain liquid water samples for offline isotopic assays (Freeze and Cherry, 1979). Although piezometers, wells, and lysimeters are useful for characterizing physical and chemical pore water transients in the subsurface, they generally lack detailed vertical depth resolution $(<1 \mathrm{~m}$ scale to detect transients) or may be too expensive to install and monitor over large spatial scales or over detailed vertical profiles. Other water isotope techniques use physical extraction of pore water from sub-samples of saturated or unsaturated cores, such as high-speed centrifugation (Allison and Hughes, 1983; Gimmi et al., 2007; Ingraham and Shadel, 1992; Kelln et al., 2001), mechanical squeezing (Kelln et al., 2001), cryogenic micro-distillation (Araguas-Araguas et al., 1995; West et al., 2006; Koeniger et al., 2011; Orolowski et al., 2013), azeotropic distillation (Allison and Hughes, 1983; Revesz and Woods, 1990), and microwave distillation (Munksgaard et al., 2014). In general, physical extraction methods are laborious and have the potential for evaporative isotopic fractionation caused by storage, multistep procedures, or by incomplete recovery of the water or evaporative loss during handling. Alternative methods for obtaining pore water isotopes from cores include radial diffusion mass-balance mixing cells (Altinier et al., 2007; Bensenouci et al., 2013; Rubel et al., 2002; Savoye et al., 2006; van der Kamp et al., 1996) or direct equilibration of the pore water in core sub-samples using helium- $\mathrm{CO}_{2}$ or a $\mathrm{He}-\mathrm{H}_{2}$ catalyst mixtures with headspace gas-water equilibration (Hendry et al., 2004; Kelln et al., 2007; Koehler et al., 2000).

Wassenaar et al. (2008) proposed a novel method for measuring the $\delta^{2} \mathrm{H}$ and $\delta^{18} \mathrm{O}$ of pore water in saturated and unsaturated geologic (core, soil) samples by using a direct vapour equilibration and laser spectrometry (DVE-LS) approach. The DVE-LS method is based on the principle that a geologic sample containing pore water in a closed system (e.g. a flexible gas-sampling bag) will quickly equilibrate with the available head space, coming to $100 \%$ relative humidity $(\mathrm{RH})$ at ambient pressures and temperatures and undergoing isotopic fractionation consistent with equilibrium fractionation within a closed system. The equilibrated $\mathrm{H}_{2} \mathrm{O}$ headspace is dynamically and quickly sampled by a laser spectrometer for online isotopic analysis. By strictly controlling the temperature and the time of $\mathrm{H}_{2} \mathrm{O}_{\text {porewater }}-\mathrm{H}_{2} \mathrm{O}_{\text {headspace equilibra- }}$ tion, the isotopic composition of headspace $\mathrm{H}_{2} \mathrm{O}$ vapour is measured from directly equilibrated saturated or unsaturated core. The well-known temperature-dependent isotopic equilibrium fractionation factors (Majoube, 1971) can be used to calculate the pore water oxygen and hydrogen isotopic composition; however, it is generally more accurate and easier to evaluate the fractionation from liquid to vapour by concurrently running identically equilibrated laboratory water standards of known isotopic values that span the expected range of the samples using DVE-LS (Wassenaar et al., 2008). The final isotope composition of the pore water sample is then normalized and reported according to the Vienna Standard
Mean Ocean Water-Standard Light Antarctic Precipitation (VSMOW-SLAP) scales.

The analytical precision of the DVE-LS method for $\delta^{2} \mathrm{H}$ and $\delta^{18} \mathrm{O}\left( \pm 0.4 \%\right.$ for $\delta^{18} \mathrm{O}$ and $\pm 2.1 \%$ for $\left.\delta^{2} \mathrm{H}\right)$ is comparable to or better than the aforementioned extractions and isotope ratio mass spectrometry (IRMS)-based direct equilibration methods (Kelln et al., 2001; Morrison et al., 2001), and significantly better than those reported for physical and chemical water extractions (Allison and Hughes, 1983; Revesz and Woods, 1990). Accuracy is assured through the application of identical treatment (IT) approaches, using controls and standards and, where available, by field comparison with isotopic data from piezometers or by other extraction methods.

The DVE-LS method has since been adopted and modified to obtain high-resolution isotopic profiles to define solute transport mechanisms, timing of hydrogeologic events, and sources of waters in near-surface environments such as soils and the unsaturated zone ( $<15 \mathrm{~m}$ depths; Garvelmann et al., 2012; Hendry and Wassenaar, 2009; Klaus et al., 2013; Mueller et al., 2014; Stumpp and Hendry, 2012; Sprenger et al., 2015), to intermediate depths ( $<100 \mathrm{~m}$ depths; Hendry et al., 2011a; Filippini et al., 2015), and on deep geological cores at basinal scales $(<500 \mathrm{~m}$ depths; Harrington et al., 2013; Hendry et al., 2013). Since the original DVE-LS publication (Wassenaar et al., 2008), we have applied this technique to a number of field studies and made a number of important technical adaptations gained from the experience of thousands of pore water isotopic analyses. We also discovered some unforeseen constraints with the DVE-LS method.

Here, we describe some of the improvements and caveats that were not anticipated at the time of method development. We assess and evaluate several aspects, including (1) the accuracy of high-resolution isotopic depth profiles by DVELS; (2) contamination impacts from a range of drilling and sample collection methods; (3) the effects of long-term sample storage in plastic gas-sampling bags and approaches to correct for it; (4) alternate gas-sampling bag materials, with the aim of increasing the storage time with no loss of sample integrity; (5) water content limits for obtaining accurate isotopic data; and (6) spectral contamination by petroleum organics. These topics are addressed in separate sections, including a discussion of relevant materials, results, and outcomes. The known issue of high salinity (e.g. cores from deep brine) is considered exceptional to most hydrogeologic water resource studies, and is discussed elsewhere (Brand et al., 2009; Koehler et al., 2013; West et al., 2010).

\section{High-resolution DVE-LS profiles versus pore waters from squeezed cores and piezometers}

The ability of the DVE-LS method to produce accurate highresolution depth profiles of the $\delta^{2} \mathrm{H}$ and $\delta^{18} \mathrm{O}$ of pore water has not been the subject of rigorous testing to date. Only 


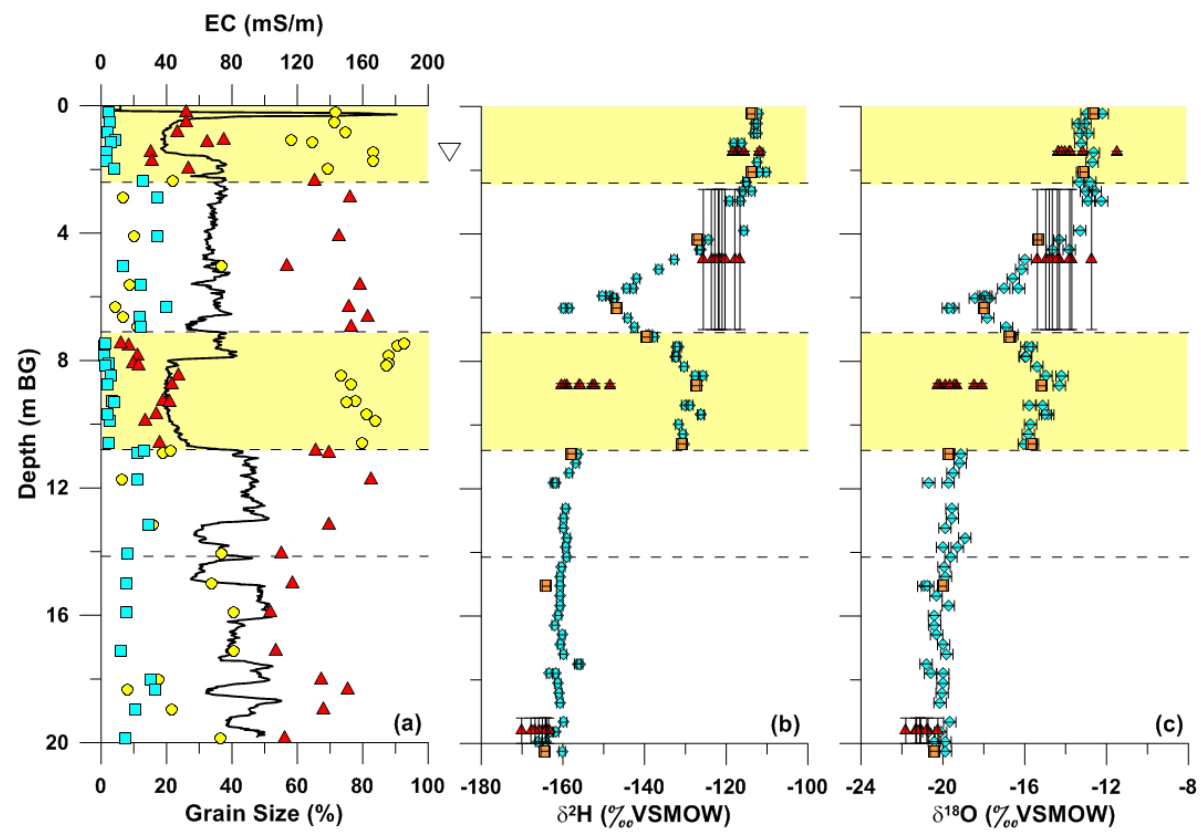

Figure 1. High-resolution profiles vs. metres below ground for (a) percent sand, silt, and clay and electrical conductivity (EC; measured using a direct push EC $\log )$, (b) $\delta^{2} \mathrm{H}$, and (c) $\delta^{18} \mathrm{O}$ near Lethbridge, Alberta, Canada. The sand, silt, and clay size fractions in (a) are presented as yellow circles, red triangles, and light blue squares, respectively. The vapour, mechanical squeezed, and piezometer values in (b) and (c) are presented as blue diamonds, orange squares, and red triangles, respectively. The vertical lines for the piezometer values represent the length of the sand pack around the screened zone. The location of the water table is presented as an inverted triangle in (a). Gravimetric water content of all samples ranged from 18 to $32 \%(n=59)$. Yellow shaded areas represent sand layers.

Bourke et al. (2015) compared pore water $\delta$ values measured using DVE-LS with water samples obtained by squeezing core samples, finding that both sets of data yield comparable isotopic results. We conducted a similar comparative test at a hydrogeologically complex site having a greater range in pore water $\delta$ values. We compared the high-resolution $(\mathrm{cm}$ scale) isotopic depth profiles of pore water determined by DVE-LS to liquid water samples obtained by both squeezing duplicate core samples and collection from four site piezometers. DVE-LS was performed on a continuous core taken from the water table (about $0.50 \mathrm{~m}$ below ground surface; $\mathrm{BG})$ to $20 \mathrm{~m} \mathrm{BG}$ at a site near Lethbridge, Alberta, Canada. Core samples were collected using a split spoon hollow stem auger at depth intervals of $30 \mathrm{~cm}(n=60)$. The percentages of sand, silt, and clay size particles were determined on core samples taken $10 \mathrm{~cm}$ above the DVE-LS core samples using the method outlined in Sperazza et al. (2004). Electrical conductivity (EC) was determined using a direct push (D-P) EC logger. Samples were analysed for pore water stable isotopes using the DVE-LS method within 14 days of field sampling. Duplicate core samples $(n=9)$ were targeted to select a wide $\delta$ range in the core hole, and were squeezed using a mechanical squeezer at $50 \mathrm{MPa}$ for $24 \mathrm{~h}$ within 30 days to obtain liquid water samples. Water samples were also collected from four standpipe piezometers installed at the drill site and analysed for stable isotopes 9 times over a 3- year period. The DVE-LS analyses were conducted on core samples using a Picarro 2120 i analyser. Liquid water samples collected from squeezed samples or piezometers were analysed by conventional liquid water laser spectrometry as described by Lis et al. (2008).

The geology of the depth profile was determined from logging, grain-size analyses, and EC logging (Fig. 1a), and consisted of a sequence of sand-rich layers (0-2.4 and 7.1$10.8 \mathrm{~m} \mathrm{BG}$ ) and silt-rich layers (2.4-7.1 and > 10.8 m BG) (Fig. 1a). The water table was at $0.46 \mathrm{~m} \mathrm{BG}$ at the time of coring, but seasonally ranged from 0.15 to $0.89 \mathrm{~m} \mathrm{BG}$.

High-resolution pore water isotopic depth profiles obtained by DVE-LS are shown in Fig. $1 \mathrm{~b}$ and c. $\mathrm{H}$ and $\mathrm{O}$ isotopes exhibited the same depth trends. The $\delta^{2} \mathrm{H}$ and $\delta^{18} \mathrm{O}$ values obtained by DVE-LS are in good comparative agreement with the squeezed pore water sample values, falling within \pm 2.0 and $\pm 0.2 \%$ o $(n=9)$, respectively. Good agreement between these two methods is supported by the observed isotopic discontinuity for both DVE-LS and squeezed pore water samples across the base of the sand layer at $10.8 \mathrm{~m}$ BG. The complex vertical depth trends of squeezed and DVE-LS profiles reflect the dynamic nature of lateral advective transport within the coarse-textured zones and diffusiondominated transport within the finer textured zones (based on the shape of the vertical profiles; however, further discussion of the definition of solute transport based on $\delta^{2} \mathrm{H}$ and 

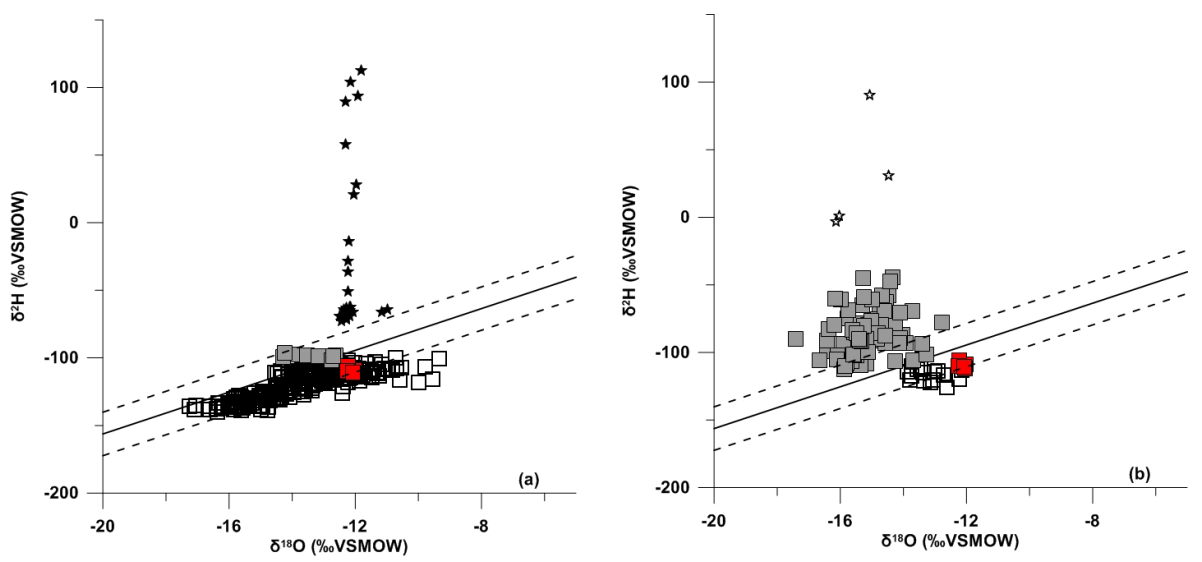

Figure 2. Cross-plot of the $\delta^{18} \mathrm{O}$ and $\delta^{2} \mathrm{H}$ values of pore water from Cretaceous shales and drill fluids at two drill sites near Esterhazy, Saskatchewan, Canada. Solid grey squares and open black squares represent contaminated and uncontaminated samples, respectively, trimmed in the field (a) and trimmed in the laboratory (b). Solid red squares represent the source water for rotary drilling, and solid and open stars represent isotopically spiked drill waters for core holes for samples trimmed in the field and laboratory, respectively. The local meteoric water line (LMWL) for Saskatoon, Saskatchewan, is also presented with associated $95 \%$ confidence intervals (after Hendry et al., 2013). Gravimetric water content of all samples ranged from 7.8 to $31.3 \%(n=101)$.

$\delta^{18} \mathrm{O}$ depth profiles is beyond the scope of this paper and the reader is referred to Hendry et al. (2015) for details). The results of isotopic analyses of water samples collected from piezometers also support the general shape of the highresolution isotopic profiles above. However, the piezometers clearly fail to capture the true hydrogeologic (and isotopic) complexity of the site, and do not reveal the actual isotopic depth profiles obtained from DVE-LS (or squeezing), likely due to spatial variability of sand layers. Thus, an interpretation of the hydrogeology at this site based solely on isotopic data obtained from piezometers would lead to completely erroneous conclusions; the complex hydrogeology is best defined using high-resolution isotopic profiling. The piezometer installed in the second sand layer, in particular $(8.75 \mathrm{~m}$ BG), shows an offset ( -28.5 and $-5.1 \%$ for $\delta^{2} \mathrm{H}$ and $\delta^{18} \mathrm{O}$, respectively) between results obtained from piezometers and those obtained from DVE-LS and squeezing. This difference was attributed to a recent rapid change in source water in this sand layer, as evidenced by the sharp isotopic interface across the lower boundary of the sand.

\section{Contamination from rotary drilling and coring methods}

In the original DVE-LS paper (Wassenaar et al., 2008), continuous saturated and unsaturated core samples were collected to $30 \mathrm{~m}$ depth in glacial till using a split spoon sampler advanced through hollow stem augers. Since that study, split spoon core sampling techniques have been successfully used with both solid and hollow stem augers or direct push drilling methods to obtain high-resolution profiles through a range of other near-surface glacial till, glaciolacustrine, and fluvial sediments (<15 m BG) (Bourke et al., 2015; Hendry and Wassenaar, 2009; Stumpp and Hendry, 2012; Turchenek, 2014). Grab samples from surficial $(<1.5 \mathrm{~m} \mathrm{BG})$ sediments collected using a hand auger have also been successfully analysed (Stumpp and Hendry, 2012).

Auger drilling and hand sample collection methods have major depth and media limitations. Because it is often difficult using auger drilling to collect solid samples at depths $>30 \mathrm{~m}$ or in highly consolidated geologic media, rotary drill methods that employ drilling fluids and split spoon core barrels are required to obtain core samples from deeper $(<500 \mathrm{~m}$ BG) formations (Hendry et al., 2011a, 2013; Schmeling, 2014). To evaluate the impact of the required drilling fluids and potential to contaminate the core pore water, a series of techniques were employed using drilling fluids spiked with $\mathrm{D}_{2} \mathrm{O}$ tracer. Estimates of potential contamination of core subsamples by drilling fluids were determined by pre-spiking the drill rig water reservoir (water was used as a drill fluid in all cases) with $0.015 \mathrm{~mL}$ of $99 \%$ deuterium oxide $\left(\mathrm{D}_{2} \mathrm{O}\right)$ per $1 \mathrm{~L}$ of water (at a cost of USD $1 \mathrm{~mL}^{-1}$ of $\mathrm{D}_{2} \mathrm{O}$ ) prior to drilling to increase the $\delta^{2} \mathrm{H}$ value of the drilling water by $>100 \%$ over natural values. In these tests, core sub-samples were collected and quickly processed in the field in a manner consistent with Wassenaar et al. (2008). All cores were field extruded and immediately trimmed to remove drilling fluid from the outer surfaces of the core prior to bagging the core sample for further processing. Sample exposure to air following core opening was limited to a few minutes. Coring, sampling, and spiking of drill fluids used in these studies are described in Hendry et al. (2011a).

In the case of rotary drilling, core waters contaminated with drill mud yielded $\delta^{2} \mathrm{H}$ values that plotted far off the expected local meteoric water line (LMWL) as exemplified by data collected from a Cretaceous shale (12 to $324 \mathrm{~m} \mathrm{BG}$ ) at 

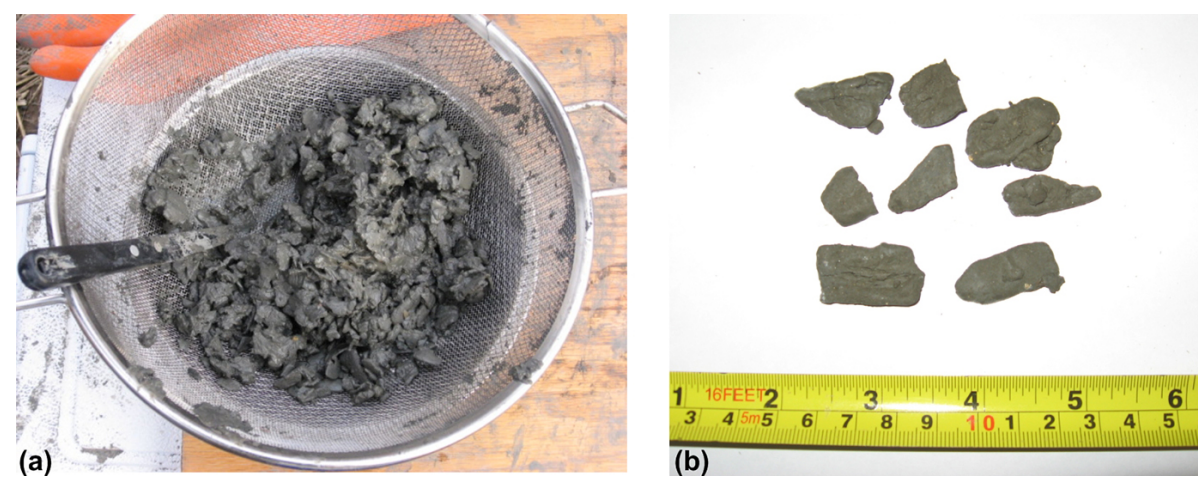

Figure 3. Evaluation of core cuttings as an alternative sample source for DVE-LS: (a) sieved chip samples after washing, and (b) wiped chip samples (typically $25 \times 15 \mathrm{~mm}$ ) prior to placement in Ziploc ${ }^{\mathrm{TM}}$ bags.

a site near Esterhazy, Saskatchewan (Fig. 2a). Here, drilling water contaminated eight of the 286 core samples analysed. Based on numerous other measurements made on core samples collected in this manner via rotary drilling at several sites across Saskatchewan, Canada, $<3 \%$ of core samples from shales collected and tested $(n=637)$ were identified as contaminated by drilling fluid. Similarly, $<9 \%$ of Quaternary till $(n=179)$ and $<7 \%$ of recent silt samples $(n=$ 55) were contaminated by drill water (data not presented). These data indicate that the DVE-LS method can provide accurate formational isotopic values for fine-textured core samples collected using rotary drilling methods followed by rapid core sampling and handling. Not surprisingly, this method proved largely ineffective on permeable geologic sediments obtained by rotary drilling. For example, $23 \%$ of saturated sand cores tested $(n=151)$ collected via rotary drilling across Saskatchewan, Canada, were contaminated by drilling water (data not presented).

The importance of rapidly collecting, trimming, and storing core samples after rotary drilling was reflected in data obtained using an alternate collection method on core samples from Cretaceous shale (324-411 m BG) at a site located $8 \mathrm{~km}$ from the site in Fig. 2a. Here, drilling and coring were conducted using rotary drilling (with $\mathrm{D}_{2} \mathrm{O}$ spiked drill water) using $3.04 \mathrm{~m} \times 75 \mathrm{~mm}$ core barrels with polyvinyl chloride (PVC) liners. Unlike the sampling approach described above, entire lengths of core from each core barrel were kept in their PVC liners, but the drilling fluid was simply drained from the core tubes, and the ends of the PVC tubes capped and sealed. These core tubes were shipped to the laboratory where they were stored for 2 days before being sub-sampled at $1 \mathrm{~m}$ resolution $(n=85)$ for isotopic analyses. In contrast to the samples extruded and trimmed immediately on-site (Fig. 2a), $84 \%$ of these samples fell above the LMWL indicating extensive contamination derived from the spiked drill water persisting in the tube (Fig. 2b). These data show that minimizing core exposure time to drilling fluid is critical; core samples should be trimmed of all drilling mud imme- diately after collection in the field to minimize isotopic contamination.

In many field programmes, the cost of rotary drilling may preclude the extra time required to collect and trim core samples for DVE-LS analyses and therefore only cuttings can be collected. Thus, we also examined whether core cuttings could be used as an alternative sample source. The efficacy of conducting DVE-LS analyses on cleaned drill cutting samples collected during rotary drilling was assessed in Cretaceous shale at a site near Luck Lake, Saskatchewan. A Chevron Drag bit was used to maximize the size of the chips during drilling. Chip samples were collected at $3 \mathrm{~m}$ depth intervals from 31 to $111 \mathrm{~m} \mathrm{BG}$ by screening the return drilling fluid through a wire mesh strainer (Fig. 3a). The drilling fluid was spiked with $\mathrm{D}_{2} \mathrm{O}$ as described above. The largest core chips (typically $25 \times 15 \mathrm{~mm}$ ) were collected from the strainer (Fig. 3b), and the outer surfaces immediately cleaned using one of two methods: wiping with paper towels to remove drill fluid or shaving the outer $2 \mathrm{~mm}$ from the entire surface. Once the outer surfaces were cleaned, the chips were placed in sealed gas-sampling bags. For comparative purposes, core samples were also collected at $3 \mathrm{~m}$ intervals using a split spoon core barrel $(3 \mathrm{~m}$ long $\times 13.8 \mathrm{~cm}$ outside diameter (OD)). These samples were immediately trimmed and placed in sealed gas-sampling bags in the field. Spiked drill water samples were collected every $10 \mathrm{~m}$ of drilling.

The $\delta^{2} \mathrm{H}$ values of pore waters from intact core samples, trimmed chips, and wiped chips from the Cretaceous shales and drill fluid were plotted versus depth (Fig. 4). These data clearly reveal that drilling fluid readily contaminated most of the chip samples, regardless of the cleaning method used. The depth profile also revealed that the degree of contamination of chip samples increased with contact time between the chips and the drilling fluid (i.e. contamination was worse in samples from deeper in the core hole due to the longer contact time). In short, DVE-LS analyses of chip samples using rotary drill methods should be avoided. 


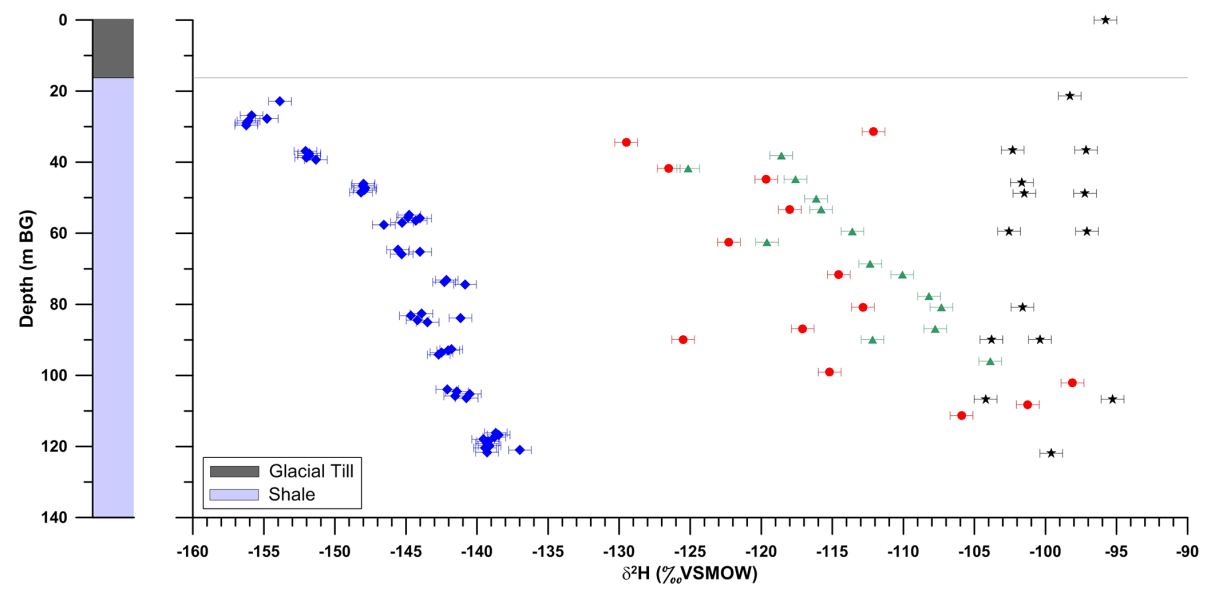

Figure 4. $\delta^{2} \mathrm{H}$ values vs. depth for pore waters measured via vapour equilibration on core samples (solid blue diamonds), trimmed chip samples (solid red circles), and wiped chip samples (solid green triangles) from Cretaceous shale at a site near Luck Lake, Saskatchewan, Canada. The $\delta^{2} \mathrm{H}$ values of the drill fluid are presented as solid black stars. The analytical error is presented as horizontal bars. Gravimetric water content of all samples ranged from 15.5 to $42.2 \%(n=80)$.

\section{Use of sonic drilling methods for saturated and unsaturated coring and DVE-LS analysis}

Sonic drilling differs from mud (water) rotary drilling in that the drill bit is physically vibrated vertically while being pushed down and rotated. It is generally used to collect continuous core samples to depths of $100 \mathrm{~m}$. The effect of wet (using deuterium oxide spiked drill water) versus dry (no fluid added) sonic core sampling for DVE-LS analyses was tested at a natural saturated site and an unsaturated waste rock pile near Sparwood, British Columbia.

Coring was conducted using a truck-mounted sonic drill rig with a $0.15-0.18 \mathrm{~m}$ internal diameter (ID) casing and $0.10 \mathrm{~m}$ ID (and occasionally $0.15 \mathrm{~m}$ ID) $3.05 \mathrm{~m}$ long core tube. The core tube was advanced $3.05 \mathrm{~m}$ before extraction of the core and advancement of the casing. Core samples were collected at $1 \mathrm{~m}$ intervals and, in the case of the wet drilling, $\mathrm{D}_{2} \mathrm{O}$ spiked drill water samples were collected from the drill rig water tank when it was full and half empty. Geologic descriptions of the core were made in the field. The isotopic composition of pore waters in core samples and the drilling fluid were analysed using DVE-LS (Wassenaar et al., 2008). Sonic drilling can rapidly heat core samples and high temperatures were suspected to cause evaporation of water in core samples; hence, the internal temperature of the cores was measured immediately after they were brought to surface.

The geology and isotopic depth profiles for the wet and dry sonic core holes at the natural site are presented in Fig. 5. The geology was characterized by sands with silt, clay-, and gravel-dominated layers. The mean temperatures ( \pm standard deviation) of the wet and dry core samples were $13.8 \pm 1.7^{\circ} \mathrm{C}(\max =16.4, \min =10.5 ; n=16)$ and $43.7 \pm 22.3^{\circ} \mathrm{C}(\max =80, \min =9.2 ; n=31)$, respectively.
The wet core samples yielded mean temperatures typically twice those measured in standpipe piezometers installed at this site $\left(\right.$ mean $=5.0 \pm 1.5^{\circ} \mathrm{C}, \max =7.8^{\circ} \mathrm{C}, \min =2.8^{\circ} \mathrm{C}$; $n=78$; Szmigielski et al., 2014). In contrast, mean temperatures measured in the dry core samples were on average $40^{\circ} \mathrm{C}$ greater than the mean in the piezometers. These data show that core temperatures at natural (saturated) sites are influenced by sonic drilling methods. The $\delta^{2} \mathrm{H}$ depth profile from the dry core hole exhibited subtle but continuous trends with depth between all samples. Overall, the wet sonic profile was consistent with the dry core-hole profile, although strong positive contamination excursions were noted for four isolated samples. Because these excursions trended towards the $\delta^{2} \mathrm{H}$ values of the $\mathrm{D}_{2} \mathrm{O}$ spiked drill water (also reflected on a cross-plot of $\delta^{2} \mathrm{H}$ and $\delta^{18} \mathrm{O}$, not presented) and three of these samples were from permeable gravel zones, it was assumed that these few anomalous values were the result of core contamination by drill fluids. Overall, the data suggest that both wet and dry sonic drilling and coring can be used with DVE-LS in most hydrogeologic environments to obtain isotopic depth profiles below the water table. The exception is permeable units, for which a dry sonic drilling and coring method should be used.

Although core sampling to generate isotopic depth profiles in shallow unsaturated zones has been established (see Introduction), sampling methods to generate vapour profiles of $\delta^{2} \mathrm{H}$ and $\delta^{18} \mathrm{O}$ through thick unsaturated zones have not been assessed. We assessed the applicability of using wet and dry sonic core sampling methods through a thick unsaturated waste rock pile near Sparwood, British Columbia. The waste rock texture was predominately sandy but contained cobble-dominated layers in the upper $13 \mathrm{~m}$ of the profile. A water table was observed at $65 \mathrm{~m} \mathrm{BG} \mathrm{(Fig.} \mathrm{6).} \mathrm{Iso-}$ tope plots of $\delta^{2} \mathrm{H}$ for the dry and wet sonic methods are pre- 


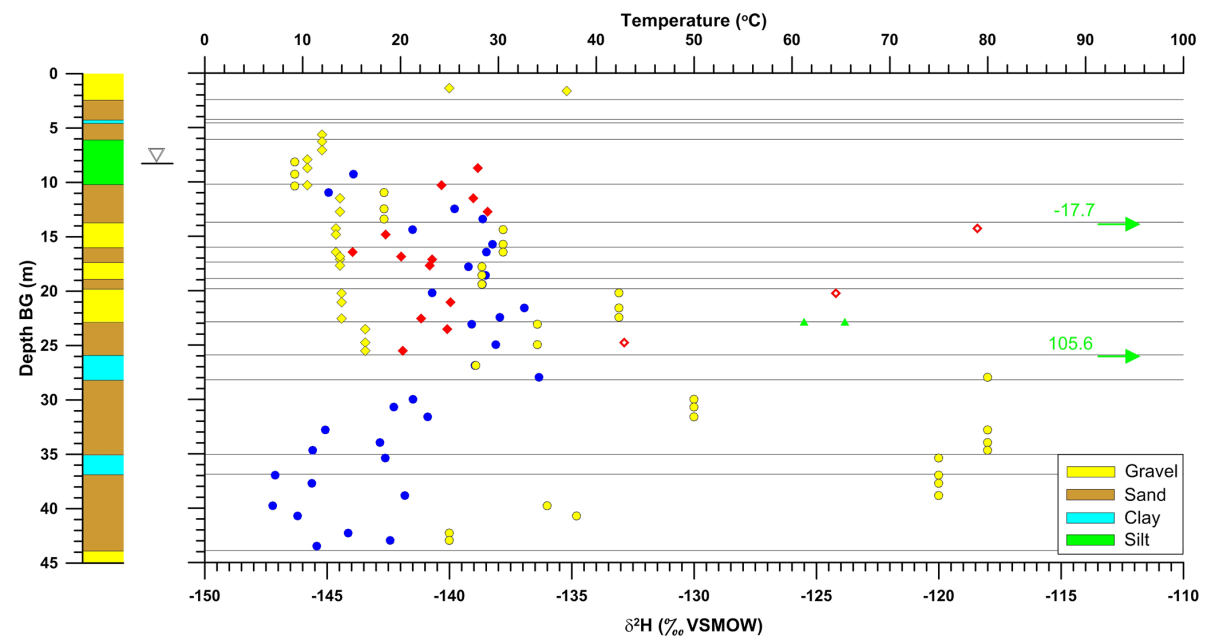

Figure 5. $\delta^{2} \mathrm{H}$ depth profiles of pore water from a complex, saturated natural geologic media located in the Elk Valley, British Columbia. Values for samples collected via dry sonic coring are represented by solid blue circles, via wet sonic and not showing evidence of contamination (or minimally so) are represented by solid red diamonds, and via wet sonic and visibly contaminated by drill fluid are represented by open red diamonds. The $\delta^{2} \mathrm{H}$ values of the drill fluid samples are represented by solid green triangles. The temperatures of the core upon extraction are represented by solid yellow circles and solid yellow diamonds for the dry sonic and wet sonic samples, respectively. The location of the water table is identified by an inverted triangle. The mean gravimetric water content of samples from adjacent wet and dry sonic core samples from the complex saturated natural site were $9.9 \pm 5.1 \%(n=19)$ and $12.6 \pm 5.1 \%(n=34)$, respectively.

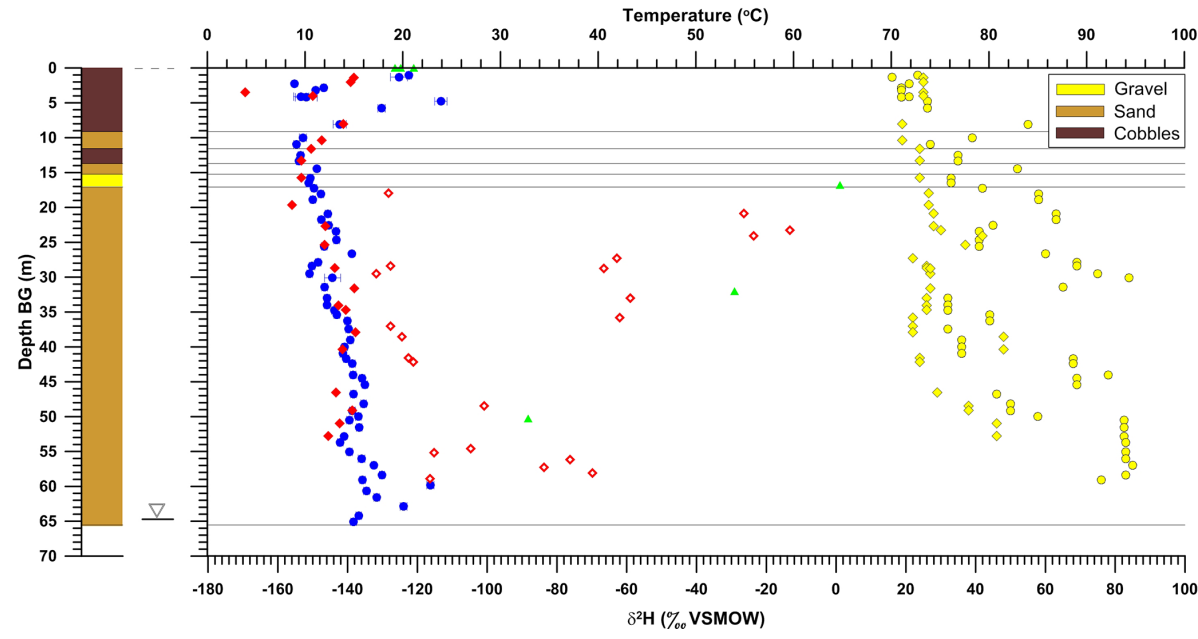

Figure 6. $\delta^{2} \mathrm{H}$ depth profiles of pore water from an unsaturated waste rock pile located in the Elk Valley, British Columbia. Samples collected via dry sonic coring are represented by solid blue circles, collected via wet sonic and not showing evidence of contamination (or minimally so) are represented by solid red diamonds, and collected via wet sonic and visibly contaminated by drill fluid are represented by open red diamonds. The $\delta^{2} \mathrm{H}$ values of the drill fluid samples are represented by solid green triangles. The temperatures of the core upon extraction are represented by solid yellow circles and solid yellow diamonds for the dry sonic and wet sonic samples, respectively. The location of the water table is identified by an inverted triangle. The mean gravimetric water content of samples from adjacent wet and dry sonic core samples from the unsaturated waste rock pile were $7.8 \pm 1.5 \%(n=35)$ and $7.6 \pm 2.0 \%(n=39)$, respectively.

sented in Fig. 6. Contamination by drill fluid during wet coring was evident in a large number of samples, as shown by elevated $\delta^{2} \mathrm{H}$ values and with depth (49\% of wet core samples were measurably contaminated). The temperature measured in both wet core-hole samples (mean $=28.9 \pm 8.1^{\circ} \mathrm{C}$, $\left.\max =48^{\circ} \mathrm{C}, \min =19^{\circ} \mathrm{C} ; n=37\right)$ and in dry core-hole samples $\left(\right.$ mean $=50.7 \pm 21.4^{\circ} \mathrm{C}, \max =85^{\circ} \mathrm{C}$, $\min =16^{\circ} \mathrm{C}$; $n=59$ ) were elevated with respect to in situ temperature profiles $\left(\right.$ mean $=11.2 \pm 4.3{ }^{\circ} \mathrm{C}, \max =29.3{ }^{\circ} \mathrm{C}, \min =1.4{ }^{\circ} \mathrm{C}$; $n=187$; unpublished data) measured by thermocouples installed from 0.0 to $81.3 \mathrm{~m} \mathrm{BG}$. As was the case for the wet and dry core-hole data from the natural site, the elevated core 


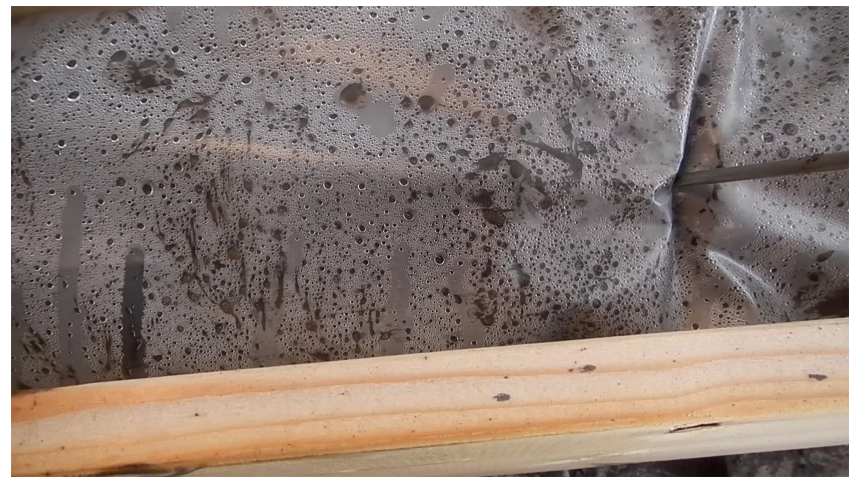

Figure 7. Vapour condensation on the inside of plastic sampling sleeve at ground surface. Core temperature at ground surface was $85^{\circ} \mathrm{C}$.

temperatures in the unsaturated waste rock were attributed to heating during sonic coring. The temperature of the unsaturated dry core samples increased with increased depth or rock strength, often reaching $60-80^{\circ} \mathrm{C}$. Opening core sleeves to collect sub-samples often resulted in a rapid loss of water vapour from the unsaturated core (Fig. 7). In some cases, loss of water vapour resulted in kinetic isotope fractionation of the pore water as evidenced by a large number of samples that plotted along an evaporitic fractionation line, with the slope of the line defined by the relative humidity in the atmosphere during sampling (Fig. 8). Although dry sonic coring eliminated the potential for sample contamination by drilling fluid, the kinetic isotope fractionation that can occur as a result of water loss from the core samples complicates interpretation of these isotope measurements, even though the depth profile can incorrectly suggest otherwise (Fig. 6). A method for correcting these profiles for fractionation associated with core heating and water loss has been developed and will be submitted for publication in the near future.

\section{Minimum water content required for DVE-LS analyses of core samples}

Based on original water content experiments with DVE-LS, Wassenaar et al. (2008) note that the accuracy of isotopic data obtained by DVE-LS became markedly and progressively positively biased for $60 \mathrm{~g}$ samples with $<5 \%$ gravimetric water content (GWC) when tested in $1 \mathrm{~L}$ sample bags, despite the gas-sampling bags having a $100 \%$ RH headspace. They concluded that the DVE-LS technique was not suitable for dry sediments with low water content.

We estimated the minimum mass of water that would be lost from the sand to bring the headspace to a saturated vapour pressure under ambient laboratory temperatures (approximately $20 \mathrm{mg}$ at $25^{\circ} \mathrm{C}$ ). The theoretical equilibrium isotope fractionation that would have occurred was then calcu-

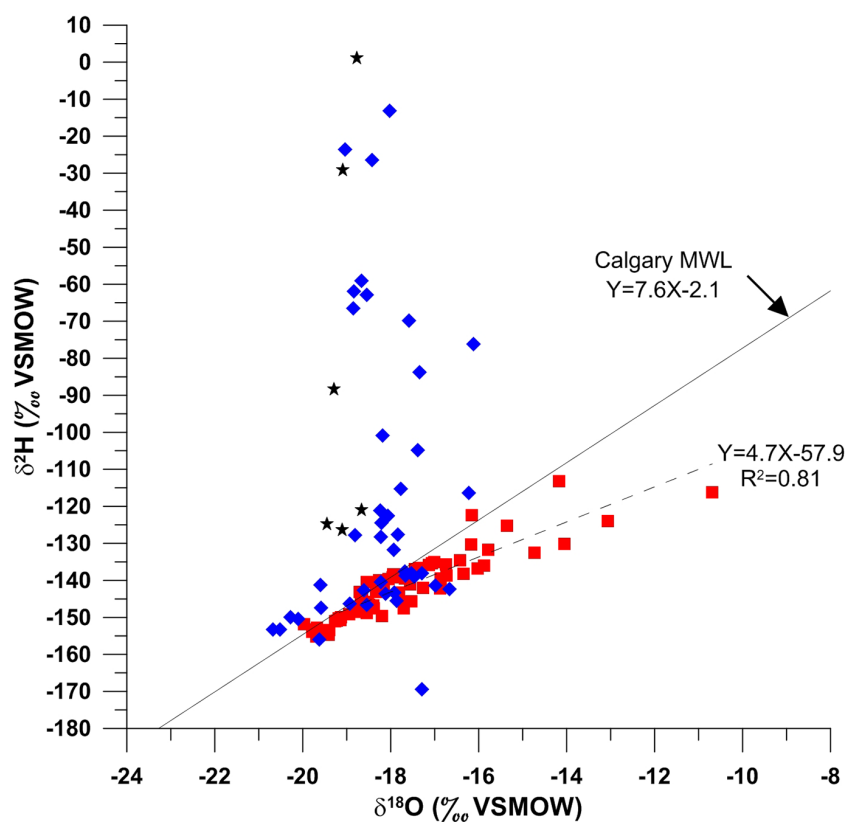

Figure 8. Cross-plot of $\delta^{18} \mathrm{O}$ and $\delta^{2} \mathrm{H}$ values of pore waters from core samples collected at two adjacent sites on an unsaturated waste rock pile near Sparwood, British Columbia. Coring was conducted using wet (solid blue diamonds) and dry (solid red squares) sonic drilling. Values for spiked drill mud are presented as solid black stars. The local meteoric water line for Calgary (Peng et al., 2004) and the best-fit (evaporitic fractionation) line for the dry sonic data set are presented as solid and dashed lines, respectively.

lated for a closed system using (Gat, 1996)

$R_{\mathrm{f}}=R_{0} /(\alpha-f(\alpha-1))$,

where $R$ is the ratio of the stable to abundant isotope in the initial (0) and final (f) water, $\alpha$ is the fractionation factor, and $f$ is the fraction of water remaining in the liquid phase following equilibration. The theoretical isotope fractionation over the range in water content compared well with those measured by Wassenaar et al. (2008) (Fig. 9), suggesting that their trends in the measured data were consistent with equilibrium isotope fractionation (reservoir effect). Minor variances between measured and calculated values in Fig. 9 were attributed to inaccuracies in the estimated mass of water loss (e.g. adsorption of water vapour to the sample bag).

The minimum 5\% GWC limit suggested by Wassenaar et al. (2008) was originally determined using $60 \mathrm{~g}$ of dry sand in a $1 \mathrm{~L}$ gas-sampling bag. This GWC equates to a mass of water in the soil of $3 \mathrm{~g}$ and corresponds to an $f$ value in Eq. (1) of approximately $99 \%$. This limit suggests that isotope fractionation as a result of water loss to the headspace and bag would be minimal in geologic samples containing more than $3 \mathrm{~g}$ of water. Samples with GWC $<5 \%$ may be analysed provided the total mass of geologic sample is increased to ensure that there is sufficient water present within the bag to eliminate additional fractionation. For example, if a sample with a 


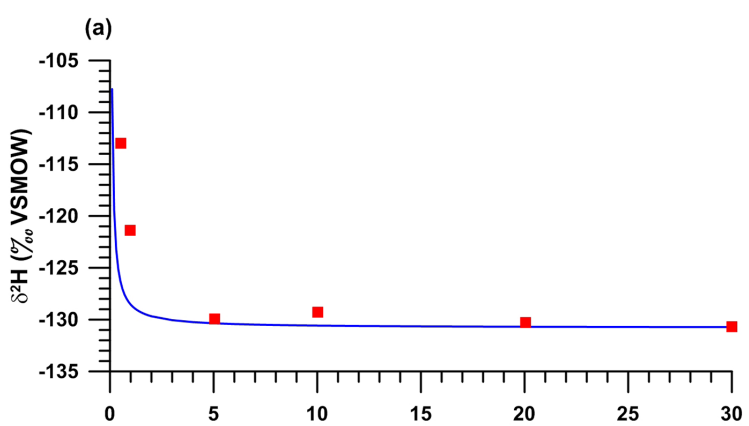

(b)

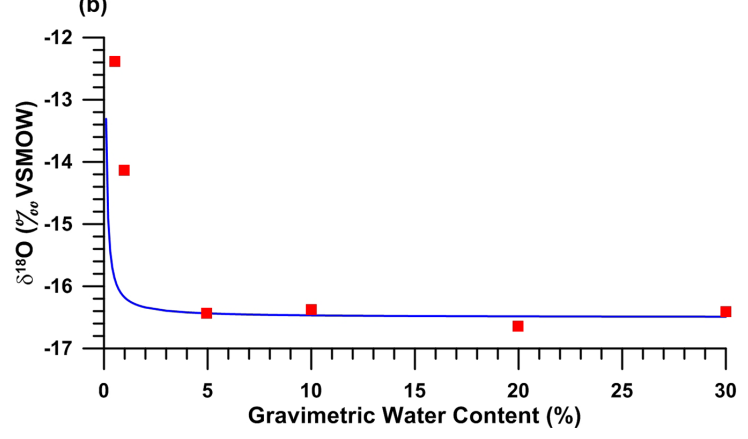

Figure 9. Calculated isotopic equilibrium fractionation of pore water in a closed system (blue line) compared to data from Wassenaar et al. (2008) measured in the headspace of Ziploc ${ }^{\mathrm{TM}}$ bags for (a) $\delta^{2} \mathrm{H}$ and (b) $\delta^{18} \mathrm{O}$.

GWC of $2 \%$ was to be analysed in a $1 \mathrm{~L}$ gas-sampling bag, the total dry mass of the soil sample would have to be increased to $>150 \mathrm{~g}$. The only limitation to this approach is the amount of available headspace available in a $1 \mathrm{~L}$ bag for at least 3 min of isotopic gas sampling. Note that all isotopic analyses presented in Figs. 1, 2, and 4-6 were conducted on samples with GWC $>5 \%$ (see details in the figure captions), consistent with the requirement established by Wassenaar et al. (2008).

\section{Effects of long-term sample storage in gas-sampling bags}

In the original DVE-LS method (Wassenaar et al., 2008), core samples were immediately placed in plastic gassampling bags and the isotopic composition of the headspace measured as soon as possible. In many field-based programmes, however, core samples must be stored for extended periods of time or shipped before isotopic analysis is possible. The impact of evaporative water loss, leakage, and subsequent isotopic fractionation during transport or sample storage in gas-sampling bags was evaluated by conducting a series of tests to determine the effect of long-term storage on DVE-LS isotope values. Tests were conducted on core samples of glacial till collected at different times from sites near Weyburn, Saskatchewan. Samples were collected using mud rotary drilling methods, trimmed, and bagged as described by Wassenaar et al. (2008). All samples were analysed using DVE-LS as outlined above and GWC determined within 14 days of collection. The samples were stored in $47 \mathrm{~L}$ coolers at room temperature. Selected core samples were taken and analysed after 6, 17, and 25 months of storage.

Core samples analysed for stable isotopes by DVE-LS within 14 days of sample collection all plotted along the LMWL (Fig. 10), indicating these samples were unaffected by short-term storage evaporative effects. However, samples analysed 6, 17, and 25 months after collection plotted farther along an evaporation line $(y=3.0 \mathrm{x}-87$; Fig. 10a). Plots of the changes in $\delta$ values over time (Fig. 10b, c) indicate a linear increase in the isotopic composition. GWC analyses show water losses from the initial values of $9.1 \pm 8.8 \%$ after 6 months, $12.0 \pm 7.0 \%$ after 17 months, and $15.0 \pm 9.6 \%$ after 25 months. These data reveal that storage of the samples in plastic gas-sampling bags for 6 months or more greatly alters the isotopic signature of the pore water, and support the requirement to perform DVE-LS analyses as soon as possible after sampling. These findings are consistent with Wassenaar et al. (2008), who reported that isotope values of core samples show evidence of evaporative isotopic enrichment after 12 days of storage, and Herbstritt et al. (2014), who reported water loss of up to $1 \mathrm{~g}$ within the first 10 days of storage in Toppits ${ }^{\circledR}$ and CB400-420 bags.

The fact that the samples fall along a well-defined evaporitic line suggests that these values can be corrected to in situ values using fractionation theory. Although details are not provided in this paper, the slope of the evaporitic line at laboratory temperatures $\left(20^{\circ} \mathrm{C}\right)$ and average indoor relative humidity for Saskatoon (35\%) is approximately 3.

\section{Use of alternative gas-sampling bag materials}

The inability to store for DVE-LS analyses for long periods in plastic gas-sampling bags poses a major limitation to field-based studies (Sect. 6). In an attempt to find a gas-sampling bag material that could increase the storage time of core samples for DVE-LS without loss of sample integrity, tests were conducted on gas-sampling bags manufactured from alternate materials. The range of gassampling bag materials included (1) crystal clear ${ }^{\mathrm{TM}}$, plastic bags with zippered tops, (2) black bags with zippered tops, (3) mylar foil bags, (4) silver foil bags, and (5) IsoPaks ${ }^{\mathrm{TM}}$. The crystal clear ${ }^{\text {TM }}$ and black bags were supplied and manufactured by Pacific Bag Inc. (http://www.pacificbag.net), the mylar bags and silver pouches (composed of polyester resin) were supplied and manufactured by sorbent systems (http://www.sorbentsystems.com/ironshield.html), and the IsoPaks ${ }^{\mathrm{TM}}$ were supplied by IsoTech Labs (http://www. isotechlabs.com). For comparative purposes, the original low-cost Ziploc ${ }^{\mathrm{TM}}$ gas-sampling bags were also assessed. 

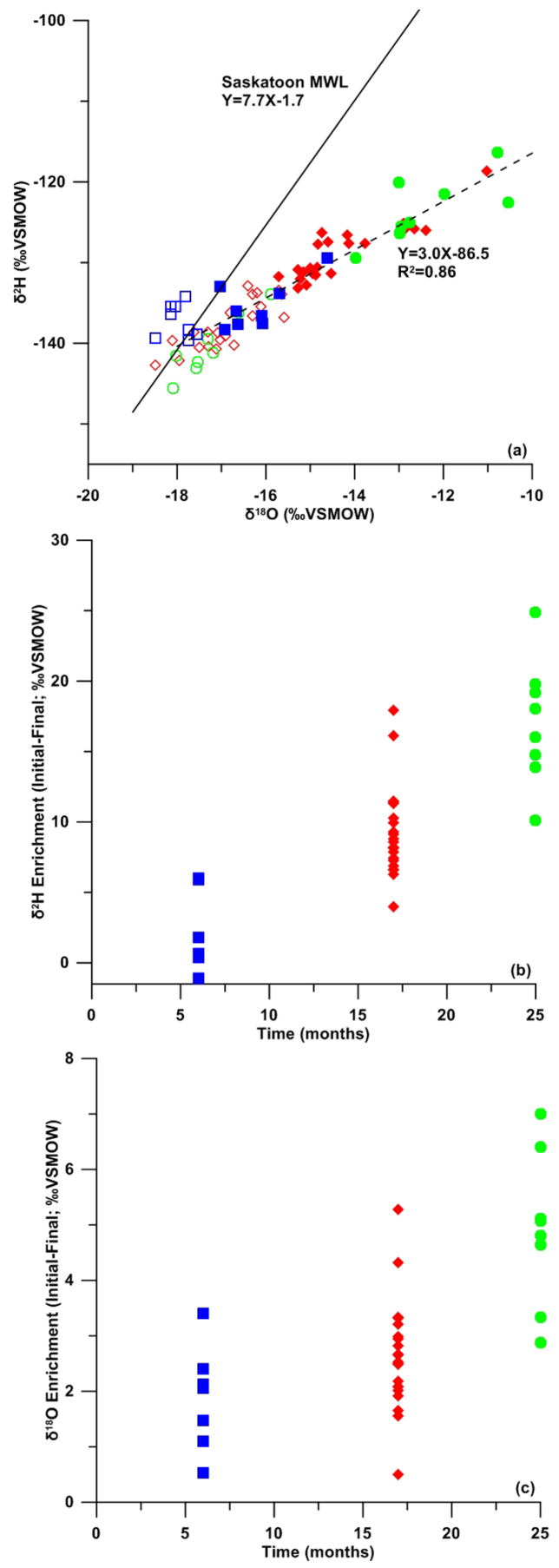

Figure 10. Effect of storage time on $\delta^{2} \mathrm{H}$ and $\delta^{18} \mathrm{O}$ of pore water in cores stored in Ziploc ${ }^{\mathrm{TM}}$ bags: (a) cross-plot of $\delta^{2} \mathrm{H}$ and $\delta^{18} \mathrm{O}$, (b) $\delta^{2} \mathrm{H}$ enrichment (initial minus final value) of pore water vs. storage time, and (c) $\delta^{18} \mathrm{O}$ enrichment (initial minus final value) of pore water vs. storage time collected from samples of glacial till. All samples were analysed within 10 days of sampling (open symbols), and after 6,16 , and 22 months of storage (solid blue squares, red diamonds, and green circles, respectively). The solid and dashed lines in (a) represent the Saskatoon Meteoric Water Line (MWL) and the best-fit evaporation line to all data, respectively.
For these tests, $5.0 \mathrm{~mL}$ of USGS 47 standard water $\left(\delta^{2} \mathrm{H}=-150.2 \%\right.$ o, $\delta^{18} \mathrm{O}=-19.8 \%$ o $)$ were placed into 30 medium-sized Ziploc ${ }^{\mathrm{TM}}$ bags, crystal clear $^{\mathrm{TM}}$ bags, black bags, silver pouches, and mylar bags and into 12 IsoPaks $^{\mathrm{TM}}$. The top of the crystal clear ${ }^{\text {TM }}$ bags, black bags, and IsoPaks ${ }^{\mathrm{TM}}$ were sealed with the zipper seals and, to ensure a complete seal, an additional heat sealing was placed above the zipper. The mylar bags and silver pouches were heat sealed (these bags do not have zipper seals). Heat sealing was performed using an American International Electric Inc. Double Impulse sealer. Medium-sized Ziploc ${ }^{\mathrm{TM}}$ freezer bags were placed inside large-sized Ziploc ${ }^{\mathrm{TM}}$ freezer bags and sealed during storage. Triplicate samples of Ziploc ${ }^{\mathrm{TM}}$, crystal clear ${ }^{\mathrm{TM}}$ bags, black bags, and mylar bags were gravimetrically weighed and analysed for stable isotopes by DVE-LS at $t=0$ (after $1 \mathrm{~h}$ of sealing), and after $1,5,10,15,30$ and 50 days. Duplicate samples of the IsoPaks ${ }^{\mathrm{TM}}$ were tested on all days except day 50. All samples were analysed by DVELS. The headspace gas phase in each bag was also analysed for light hydrocarbons $\left(\mathrm{C}_{1}-\mathrm{C}_{6}\right)$ after vapour isotope analysis on day 0 and 1 using an Agilent 7890 Gas Chromatograph to check for potential material-derived spectral interferences that would affect the laser isotope analyser. The precision of hydrocarbon analyses was $<5 \%$. No measurable hydrocarbons were detected on day 0 or 1 in the Ziploc ${ }^{\mathrm{TM}}$ bags, crystal clear $^{\mathrm{TM}}$ bags, and IsoPaks ${ }^{\mathrm{TM}}$; however, hydrocarbons were detected in the black and mylar bags and silver pouches on day 0 and 1 . Based on these findings, hydrocarbon analyses were performed on the black and mylar bags and silver pouches on day $5,10,15,30$, and 50 .

Water loss in the bags over time is presented in Fig. 11a. Over 50 days of testing, the average water loss from the Ziploc $^{\mathrm{TM}}$, crystal clear ${ }^{\mathrm{TM}}$ bags, and IsoPak ${ }^{\mathrm{TM}}$ bags was considerable at $0.61 \pm 0.07,0.87 \pm 0.10$, and $0.26 \pm 0.18 \mathrm{~g}$, respectively. In contrast, water loss from the mylar, black bags, and silver pouches over the test period was negligible at $0.02 \pm 0.01,0.05 \pm 0.02$, and $0.03 \pm 0.03 \mathrm{~g}$, respectively. Water loss in the Ziploc ${ }^{\mathrm{TM}}$ bags, crystal clear ${ }^{\mathrm{TM}}$ bags, and IsoPaks ${ }^{\mathrm{TM}}$ was also reflected in considerable evaporitic isotope fractionation (Fig. 11b, c). For example, the mean isotopic enrichments over the test period ranged up to $+11.4 \%$ ond $+4.5 \%$ o for $\delta^{2} \mathrm{H}$ and $\delta^{18} \mathrm{O}$, respectively, in the crystal clear ${ }^{\mathrm{TM}}$ bags. The negative deviation of $\delta^{2} \mathrm{H}$ and $\delta^{18} \mathrm{O}$ in mylar and black bags on day $0,1,5,10,15$, 30 , and 50 and in silver pouches on day 15, 30, and 50 was consistent with the presence of volatile organic contaminants that can cause isotopologue interferences with lasermeasured $\delta^{2} \mathrm{H}$ and $\delta^{18} \mathrm{O}$ (see Sect. 8, below). The presence of organic contaminants in these bags was confirmed by the presence of hexane (and presumably other organics) (data not presented). In summary, water loss measured in the Ziploc ${ }^{\mathrm{TM}}$ bags, crystal clear ${ }^{\mathrm{TM}}$ bags, and IsoPaks ${ }^{\mathrm{TM}}$ resulted in considerable evaporitic water loss and isotope fractionation (i.e. isotopic enrichment) commencing around day $10-15$, thus limiting the usefulness of these gas-sampling 



Figure 11. Analytical results (mean and standard deviation of triplicate samples) of (a) water loss, (b) $\delta^{2} \mathrm{H}$, (c) $\delta^{18} \mathrm{O}$ in pore water with time for each bag tested, and (d) water loss vs. deviation from the $\delta^{18} \mathrm{O}$ isotope standard value. Types tested included Ziploc ${ }^{\mathrm{TM}}$ bags $(\mathrm{blue}$ squares), crystal clear ${ }^{\mathrm{TM}}$ bags (green inverted triangles), mylar bags (red diamonds), black bags (black triangles), IsoPaks ${ }^{\mathrm{TM}}$ (purple circles), and silver pouches (pale blue stars). The $\delta^{2} \mathrm{H}$ and $\delta^{18} \mathrm{O}$ of the test pore water are presented as horizontal solid lines, with the associated standard errors presented as dashed lines $\left(\delta^{2} \mathrm{H}= \pm 0.8 \%\right.$; $\delta^{18} \mathrm{O}= \pm 0.3 \%$ ).

bags for storage past this time period; this is consistent with the findings presented in Sect. 6. Despite limited long-term storage capabilities of the Ziploc ${ }^{\mathrm{TM}}$ gas-sampling bags, they are as good as the crystal clear $^{\mathrm{TM}}$ bags or IsoPaks ${ }^{\mathrm{TM}}$ for short-term sample collection and storage for DVE-LS analyses. Based on the cost of the Ziploc ${ }^{\mathrm{TM}}$ bags, crystal clear ${ }^{\mathrm{TM}}$ bags, and IsoPaks ${ }^{\mathrm{TM}}$ (USD 26/100 bags, USD 18/100 bags, and USD 1050/100 bags), the Ziploc ${ }^{\mathrm{TM}}$ bags were cost effective and readily available. Mylar bags, black bags, and silver pouches (USD 41/100 bags, USD 16/100 bags, and USD 24/100 bags) were not suitable for the DVE-LS method because of the possibility of contamination by volatile organics.

\section{Spectral contamination by volatile organic compounds in core samples}

Some geological formations, and particularly those with organic-rich sediments, may host bacterial populations that produce biogenic gases or may contain gaseous hydrocarbons that migrate from depth over geologic timescales (Brand et al., 2009; Hendry et al., 2011b; Schmidt et al., 2012). Unfortunately, a number of hydrocarbons and other volatile organic compounds are known to cause serious spectral interferences for water isotope analysers. We encountered core samples in some Cretaceous shales that contained considerable concentrations of sedimentary $\mathrm{CH}_{4}$ that seriously affected equilibrium pore water isotopic measurements using the DVE-LS method (Pratt et al., 2014). While spectral corrections for the effect of some specific volatile organic compounds (e.g. methane, alcohols) are feasible up to a few 
vol \% concentrations (Hendry et al., 2011b), it is typically not known if gaseous hydrocarbons are present in core samples.

Rather than attempting to resolve and post-correct for organic spectral interference, we tried several methods for sample headspace hydrocarbon removal: (1) a $21 \mathrm{~cm}$ long $\mathrm{CuO}$ quartz oxidation tube furnace interface at $>950{ }^{\circ} \mathrm{C}$, (2) a reverse flow Nafion scrubber, and (3) an activated carbon tube. Each was placed in line between the pore water gassampling bag and the laser spectrometer sample inlet (Pratt et al., 2014). Only the $\mathrm{CuO}$ oven removed $100 \%$ of the hydrocarbons at concentrations up to about $5 \mathrm{vol} \%$ as $\mathrm{C}_{1}-\mathrm{C}_{6}$. Although hydrocarbons were still combusted, at concentrations $>5 \mathrm{vol} \%$ the impact of additional $\mathrm{H}_{2} \mathrm{O}$ derived from the burning of the hydrocarbons (having unknown but generally isotopically depleted ${ }^{2} \mathrm{H}$ content) adversely affected the corresponding pore water results. Further, because oxygen atoms in the sample $\mathrm{H}_{2} \mathrm{O}$ vapour exchange oxygen atoms through the $\mathrm{CuO}$ catalyst and $\mathrm{O}_{2}$ at high temperatures, $\delta^{18} \mathrm{O}$ values for pore waters were not possible with this approach (cf. Koehler and Wassenaar, 2012). The Nafion gas scrubber construction and operation introduced errors in the isotopic signature. For water molecules to pass through the Nafion membrane, they must pass through the pore space in the membrane in a stacked fashion. These molecules are trapped when water vapour ceases to be passed through the tube, and it was not possible to strip the trapped water vapour molecules between samples. Problems were also encountered with the flow rates of water passing through the membrane being too slow to allow for laser spectrometer measurements. The Nafion tube did, however, remove 98-100\% of methane at concentrations up to $<5 \mathrm{vol} \%$, but in so doing only provided a maximum water vapour concentration of 800 ppmv, far below the requirement for measurement on the Picarro. The measured isotopic values exhibited no correlation to the standard water value being evaluated, making the method unacceptable. The activated carbon filtration system was also successful in removing methane, but also absorbed most of the water vapour in the sample stream, causing a null measurement on the laser spectrometer. In summary, a catalytic oxidation interface could potentially overcome some organic gas interferences, provided hydrocarbons are not present at concentrations $>5 \mathrm{vol} \%$, but this methodological addition only allows for pore water $\delta^{2} \mathrm{H}$ measurements.

\section{Summary, conclusions, and future research}

The stable isotopes of pore water $\left(\delta^{2} \mathrm{H}, \delta^{18} \mathrm{O}\right)$ in unsaturated and saturated zone geologic media are important hydrologic tracers that can be used to determine the origin, movement, and flux of water in resource evaluations; inform water cycle studies; evaluate groundwater contamination; and determine soil vapour fluxes. A method of measuring the stable isotope composition of pore water $\left(\delta^{2} \mathrm{H}, \delta^{18} \mathrm{O}\right)$ obtained from unsat- urated and saturated zone geologic media using direct vapour equilibration laser spectrometry (DVE-LS) was recently developed by Wassenaar et al. (2008) and is becoming a more commonly used method. Since its development, our research team has used the DVE-LS method on thousands of samples from a variety of media. This study summarizes some of our testing, which gives facts and information on the use of the method.

A good comparative agreement was obtained between core pore water $\delta^{2} \mathrm{H}$ and $\delta^{18} \mathrm{O}$ values obtained using DVE-LS and conventionally squeezed samples. In complex hydrogeologic settings, high-resolution DVE-LS depth profiles provide superior isotopic data compared to long-screened or nested piezometers.

When drilling allows, core samples collected below the water table for DVE-LS analyses are best collected without the use of drill water because it can contaminate the pore water isotope signature. In cases where drill fluids are required for drilling, spiking the drill fluid with a $\delta^{2} \mathrm{H}$ tracer has proven to be of value in defining core contamination. Core samples collected using water rotary or wet sonic methods from less permeable zones (e.g. tills and shales) are generally not impacted by drill fluids. In contrast, core samples collected from permeable zones (e.g. sands) should be analysed and the resulting data interpreted with caution because they can be contaminated by drill water. Further, the use of chip samples collected during water rotary drilling for DVELS analyses should be avoided because the samples can be quickly contaminated by drill fluids. DVE-LS analyses on core samples collected from thick unsaturated zones using wet and dry sonic methods should be avoided due to contamination by drill water and heating during sonic coring resulting in kinetic fractionation, respectively. In addition, representative DVE-LS analyses of core samples with gravimetric water contents $<5 \%$ can be made provided the total mass of geologic sample in the Ziploc ${ }^{\mathrm{TM}}$ bags is adequate to minimize fractionation.

Ziploc $^{\mathrm{TM}}$ bags were determined to as good as DVE-LS analyses of, if not better than, other sample bags tested. They are also cost effective and readily available. Core testing showed that core samples should be trimmed and bagged in the field as soon after collection as possible. Ideally, DVELS analyses should be undertaken within 10 days of sampling, as loss of water and evaporitic effects on DVE-LS analyses were evident after about 6 months of storage. DVELS results can be obtained on samples containing more than $3 \mathrm{~g}$ of water when analysed in $1 \mathrm{~L}$ sample bags.

Additional methodological studies to find a gas-sampling bag that can be used to store core samples from extended periods of time as well as a method to remove hydrocarbons from vapour samples without altering the $\delta^{2} \mathrm{H}$ and $\delta^{18} \mathrm{O}$ values are warranted. 
Acknowledgements. Technical assistance was provided by V. Chostner and T. Tiffin. Financial support was provided by NSERC through Industrial Chairs to MJH and SLB, Cenovus Energy, Teck Resources Ltd., the Canadian Water Network of the Network of Centres of Excellence, the Alberta Irrigation Projects Association, and Alberta Agriculture and Rural Development. Temperature measurements in the waste rock pile using thermocouples were made by O'Kane Consultants and in the core samples by SRK Consulting.

Edited by: C. Stumpp

\section{References}

Allison, G. B. and Hughes, M. W.: The use of natural tracers as indicators of soil-water movement in a temperate semi-arid region, J. Hydrol., 60, 157-173, doi:10.1016/0022-1694(83)90019-7, 1983.

Altinier, M. V., Savoye, S., Michelot, J.-L., Beaucaire, C., Massault, M., Tessier, D., and Waber, H. N.: The isotopic composition of porewater from Tournemire argillite (France): An intercomparison study, Phys. Chem. Earth Pt A/B/C, 32, 209-218, doi:10.1016/j.pce.2006.02.047, 2007.

Araguas-Araguas, L., Rozanski, K., Gonfiantini, R., and Louvat, D.: Isotope effects accompanying vacuum extraction of soil water for stable isotope analyses, J. Hydrol., 168, 159-171, doi:10.1016/0022-1694(94)02636-P, 1995.

Bensenouci, F., Michelot, J. L., Matray, J. M., Savoye, S., Tremosa, J., and Gaboreau, S.: Profiles of chloride and stable isotopes in pore-water obtained from a 2000-m deep borehole through the Mesozoic sedimentary series in the eastern Paris Basin, Phys. Chem. Earth, Pt A/B/C, 65, 1-10, doi:10.1016/j.pce.2011.10.024, 2013.

Bourke, S. A., Turchenek, J., Schmeling, E., Mahmood, F. N., Olson, B. M., and Hendry, M. J.: Comparison of continuous core profiles and monitoring wells for assessing groundwater contamination by agricultural nitrate, Ground Water Monit. R., 35, 110 117, doi:10.1111/gwmr.12104, 2015.

Brand, W. A., Geilmann, H., Crosson, E. R., and Rella, C. W.: Cavity ring-down spectroscopy versus high temperature conversion isotope ratio mass spectrometry; a case study on $\delta^{2} \mathrm{H}$ and $\delta^{18} \mathrm{O}$ of pure water samples and alcohol/water mixtures, Rapid Commun. Mass Sp., 23, 1879-1884, doi:10.1002/rcm.4083, 2009.

Clark, I. D. and Fritz, P.: Environmental Isotopes in Hydrogeology, CRC Press/Lewis Publishers, Boca Raton, Florida, USA, 329 pp., 1997.

Filippini, M., Stumpp, C., Niejenhuis, I., Richnow, H. H., and Gargini, A.: Evaluation of aquifer recharge and vulnerability in an alluvial lowland using environmental tracers. J. Hydrol. doi:10.1016/j.jhydrol.2015.07.055, accepted, 2015.

Freeze, R. A. and Cherry, J. A.: Groundwater, Prentice Hall, Englewood Cliffs, New Jersey, USA, 604 pp., 1979.

Garvelmann, J., Kulls, C., and Weiler, M.: A porewater-based stable isotope approach for the investigation of subsurface hydrological processes, Hydrol. Earth Syst. Sci., 16, 631-640, doi:10.5194/hess-16-631-2012, 2012.

Gat, J. R.: Oxygen and hydrogen isotopes in the hydrologic cycle. Annu. Rev. Earth Pl. Sc., 24, 225-262, doi:10.1146/annurev.earth.24.1.225, 1996.
Gimmi, T., Waber, H. N., Gautschi, A., and Rubel, A.: Stable water isotopes in pore water of Jurassic argillaceous rocks as tracers for solute transport over large spatial and temporal scales. Water Resour. Res., 43, doi:10.1029/2005WR004774, 2007.

Harrington, G. A., Gardner, W. P., Smerdon, B. D., and Hendry, M. J.: Palaeohydrological insights from natural tracer profiles in aquitard porewater, Great Artesian Basin, Australia, Water Resour. Res., 49, 4054-4070, doi:10.1002/wrcr.20327, 2013.

Hendry, M. J. and Wassenaar, L. I.: Inferring heterogeneity in aquitards using high-resolution $\delta \mathrm{D}$ and $\delta^{18} \mathrm{O}$ profiles, Ground Water, 47, 639-645, doi:10.1111/j.1745-6584.2009.00564.x, 2009.

Hendry, M. J., Kelln, C. J., Wassenaar, L. I., and Shaw, J.: Characterizing the hydrogeology of a complex clay-rich aquitard system using detailed vertical profiles of stable isotopes of water, J. Hydrol., 293, 47-56, doi:10.1016/j.jhydrol.2004.01.010, 2004.

Hendry, M. J., Barbour, S. L., Zettl, J., Chostner, V., and Wassenaar, L. I.: Controls on the long-term downward transport of $\delta^{2} \mathrm{H}$ of water in a regionally extensive, two-layered aquitard system, Water Resour. Res., 4, doi:10.1029/2010WR010044, 2011 a.

Hendry, M. J., Richman, B., and Wassenaar, L. I.: Correcting for methane interferences on $\delta^{2} \mathrm{H}$ and $\delta^{18} \mathrm{O}$ measurements in pore water using $\mathrm{H}_{2} \mathrm{O}_{\text {(liquid) }}-\mathrm{H}_{2} \mathrm{O}_{\text {(vapor) }}$ equilibration laser spectroscopy, Anal. Chem., 83, 5789-5796, doi:10.1021/ac201341p, 2011b.

Hendry, M. J., Barbour, S. L., Novakowski, K., and Wassenaar, L. I.: Palaeohydrogeology of the Cretaceous Sediments of the Williston Basin using Stable Isotopes of Water, Water Resour. Res., 49, 4580-4592, doi:10.1002/wrcr.20321, 2013.

Hendry, M. J., Barbour, S. L., and Schmeling, E.: Defining nearsurface groundwater flow regimes in the semi-arid glaciated plains of North America, submitted to Isot. Environ. Healt. S., 2015.

Herbstritt, B., Limprecht, M., Gralher, B., and Weiler, M.: Effects of soil properties on the apparent water-vapor isotope equilibrium fractionation: Implications for the headspace equilibration method [poster presentation]. UNI Freiburg: http://www. hydro.uni-freiburg.de/publ/pubpics/post229 (last access: 7 October 2015), 2014.

Ingraham, N. L. and Shadel, C.: A comparison of the toluene distillation and vacuum/heat methods for extracting soil water for stable isotopic analysis, J. Hydrol., 140, 371-387, doi:10.1016/0022-1694(92)90249-U, 1992.

Kelln, C. J., Wassenaar, L. I., and Hendry, M. J.: Stable isotopes $\left(\delta^{18} \mathrm{O}, \delta^{2} \mathrm{H}\right)$ of pore waters in clay-rich aquitards: A comparison and evaluation of measurement techniques, Ground Water Monit. R., 21, 108-116, doi:10.1111/j.17456592.2001.tb00306.x, 2001.

Kelln C. J., Barbour, S. L., and Qualizza, C.: Preferential flow in a reclamation cover: Hydrological and geochemical response, J. Geotech. Geoenviron. Eng., 133, 1277-1289, doi:10.1061/(ASCE)1090-0241(2007)133:10(1277), 2007.

Klaus, J., Zehe, E., Elsner, M., Kulls, C., and McDonnell, J. J.: Macropore flow of old water revisited: experimental insights from a tile-drained hillslope, Hydrol. Earth Syst. Sci., 17, 103118, doi:10.5194/hess-17-103-2013, 2013.

Koehler, G. and Wassenaar, L. I.: Determination of the hydrogen isotopic compositions of organic materials and hydrous minerals 
using thermal combustion laser spectroscopy, Anal. Chem., 84, 3640-3645. doi:10.1021/ac3000489, 2012.

Koehler, G., Wassenaar, L. I., and Hendry, M. J.: An automated technique for measuring $\delta \mathrm{D}$ and $\delta^{18} \mathrm{O}$ values of porewater by direct $\mathrm{CO}_{2}$ and $\mathrm{H}_{2}$ equilibration, Anal. Chem., 72, 5659-5664, doi:10.1021/ac000498n, 2000.

Koehler, G., Wassenaar, L. I., and Hendry, M. J.: Measurement of stable isotope activities in saline aqueous solutions using optical spectroscopy methods, Isot. Environ. Healt. S., 49, 378-386, doi:10.1080/10256016.2013.815183, 2013.

Koeniger, P., Marshall, J. D., Link, T., and Mulch, A.: An inexpensive, fast and reliable method for vacuum extraction of soil and plant water for stable isotope analyses by mass spectrometry, Rapid Commun. Mass Sp., 25, 3041-3048, 2011.

Lis, G., Wassenaar, L. I., and Hendry, M. J.: High-precision laser spectroscopy $\mathrm{D} / \mathrm{H}$ and ${ }^{18} \mathrm{O} /{ }^{16} \mathrm{O}$ measurements of microliter natural water samples, Anal. Chem., 80, 287-293, doi:10.1021/ac701716q, 2008.

Majoube, M.: Fractionnement en oxygene-18 et en deuterium entre l'eau et sa vapeur, J. Chim. Phys., 68, 1423-1436, 1971.

Morrison, J., Brockwell, T., Merren, T., Fourel, F., and Phillips, A. M.: On-line high-precision stable hydrogen isotopic analyses on nanoliter water samples, Anal. Chem., 73, 3570-3575, doi:10.1021/ac001447t, 2001.

Mueller, M. H., Alaoui, A., Kuells, C., Leistert, H., Meusburger, K., Stumpp, C., Weiler, M., and Alewell, C.: Tracking water pathways in steep hillslopes by $\delta^{18} \mathrm{O}$ depth profiles of soil water, J. Hydrol., 519, 340-352, doi:10.1016/j.jhydrol.2014.07.031, 2014.

Munksgaard, N. C., Cheesman, A. W., Wurster, C. M., Cernusak, L. A., and Bird, M, I.: Microwave extraction-isotope ratio infrared spectroscopy (ME-IRIS): a novel technique for rapid extraction and in-line analysis of $\delta^{18} \mathrm{O}$ and $\delta^{2} \mathrm{H}$ values of water in plants, soils and insects, Rapid Comm. Mass Sp., 28, 2151-2161, 2014.

Orolowski, N., Frede, H. G., Brüggemann, N., and Breuer, L.: Validation and application of a cryogenic vacuum extraction system for soil and plant water extraction for isotope analysis, J. Sens. Sens. Syst. 2, 179-193, doi:10.5194/jsss-2-179-2013, 2013.

Peng, H., Mayer, B., Harris, S., and Krouse, R.: A 10-yr record of stable isotope ratios of hydrogen and oxygen in precipitation at Calgary, Alberta, Canada, Tellus, 56B, 147-159, 2004.

Pratt, D. L., Hendry, M. J., Barbour, L., and Schmeling, E.: Optimization and configuration of a hydrocarbon gas removal system for the determination of $\delta^{2} \mathrm{H}$ and $\delta^{18} \mathrm{O}$ on Picarro CRDS. GSA Annual Meeting, Vancouver, British Columbia, 19-22 October 2014, Session 161-2, 2014.

Revesz, K. and Woods, P. H.: A method to extract soil water for stable isotope analysis. J. Hydrol., 115, 397-406, doi:10.1016/0022-1694(90)90217-L, 1990.

Rubel, A. P., Sonntag, C., Lippmann, J., Pearson, F. J., and Gautschi, A.: Solute transport in formations of very low permeability: profiles of stable isotope and dissolved noble gas contents of pore water in the Opalinus Clay, Mont Terri, Switzerland, Geochim. Cosmochim. Ac., 66, 1311-1321, doi:10.1016/S00167037(01)00859-6, 2002.
Savoye, S., Michelot, J., Wittebroodt, C., and Altinier, V. M.: Contribution of the diffusive exchange method to the characterization of pore-water in consolidated argillaceous rocks, J. Contam. Hydrol., 86, 87-104, doi:10.1016/j.jconhyd.2006.02.010, 2006.

Schmeling, E.: Characterization of the hydrogeology and solute transport in a geologically complex, fractured, late-cretaceous shale, Fort a la Corne Kimberlite field, Saskatchewan, Canada. M.S. thesis, University of Saskatchewan, Saskatoon, Canada, 2014.

Schmidt, M., Maseyk, K., Lett, C., Biron, P., Richard, P., Bariac, T., and Seibt, U.: Reducing and correcting for contamination of ecosystem water stable isotopes measured by isotope ratio infrared spectroscopy, Rapid Commun. Mass Spectrom., 26, 141153, 2012.

Sperazza, M., Moore, J. N., and Hendrix, M. S.: High-resolution particle size analysis of naturally occurring very fine-grained sediment through laser diffractometry, J. Sediment. Res., 74, 736-743, doi:10.1306/031104740736, 2004.

Sprenger, M., Volkmann, T. H. M., Blume, T., and Weiler, M.: Estimating flow and transport parameters in the unsaturated zone with pore water stable isotopes, Hydrol. Earth Syst. Sci., 19, 2617-2635, doi:10.5194/hess-19-2617-2015, 2015.

Stumpp, C. and Hendry, M. J.: Spatial and temporal dynamics of water flow and solute transport in a heterogeneous glacial till: The application of high-resolution profiles of $\delta^{18} \mathrm{O}$ and $\delta^{2} \mathrm{H}$ in pore waters, J. Hydrol., 438-439, 203-214, doi:10.1016/j.jhydrol.2012.03.024, 2012.

Szmigielski, J. T., Hendry, M. J., and Barbour, L.: Hydrogeological characterization of a groundwater system down gradient of a coal waste rock spoil, GSA Annual Meeting, Vancouver, British Columbia, 19-22 October 2014, Session 296-8, 2014.

Turchenek, J.: Defining the distribution, source, fate and transport of nitrate in groundwater beneath an agriculturally intensive region using high-resolution profiling methods, M. S. thesis, University of Saskatchewan, Saskatoon, Saskatchewan, 2014.

van der Kamp, G., Van Stempvoort, D. R., and Wassenaar, L. I.: The radial diffusion method 1 . Using intact cores to determine isotopic composition, chemistry, and effective porosities for groundwater in aquitards, Water Resour. Res., 32, 1815-1822, doi:10.1029/95WR03719, 1996.

Wassenaar, L. I., Hendry, M. J., Chostner, V. L., and Lis, G. P.: High resolution pore water $\delta^{2} \mathrm{H}$ and $\delta^{18} \mathrm{O}$ measurements by $\mathrm{H}_{2} \mathrm{O}_{\text {(liquid) }}-\mathrm{H}_{2} \mathrm{O}_{\text {(vapor) }}$ equilibration laser spectroscopy, Environ. Sci. Technol., 42, 9262-9267, doi:10.1021/es802065s, 2008.

West, A. G., Patrickson, S. J., and Ehleringer, J. R.: Water extraction times for plant and soil materials used in stable isotope analysis, Rapid Commun. Mass Sp., 20, 1317-1321, 2006.

West, A. G., Goldsmith, G. R., Brooks, P. D., and Dawson, T. E.: Discrepancies between isotope ratio infrared spectroscopy and isotope ratio mass spectrometry for the stable isotope analysis of plant and soil water, Rapid Commun. Mass Sp., 24, 1948-1954, doi:10.1002/rcm.4597, 2010. 